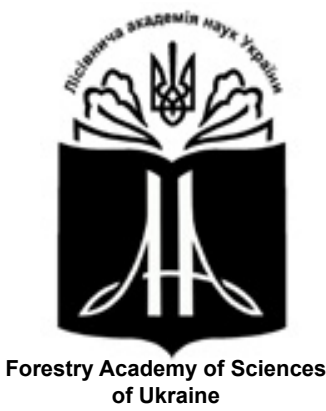

Наукові праці Лісівничої академії наук України Proceedings of the Forestry Academy of Sciences of Ukraine

http://fasu.nltu.edu.ua https://doi.org/10.15421/411913

Article received 2018.10.29

Article accepted 2019.03.28
ISSN 1991-606X print

ISSN 2616-5015 online

(a) $\triangle$ Correspondence author

Valentyna Meshkova

Valentynameshkova@gmail.com

Pushkinska str., 86, Kharkiv, 61024, Ukraine

$U D C 630.4$

\title{
Health condition parameters for deciduous trees in the forest stands of Trostyanetske Forest Enterprise
}

\author{
V.L. Meshkova', T.S. Pyvovar', O.V. Tovstukha
}

The aim of research was to evaluate the variability and relations with forest health condition its main parameters (defoliation, dieback and epicormic shoots occurrence) in seven tree species: Norway maple (Acer platanoides L.), black alder (Alnus glutinosa L.), silver birch (Betula pendula Roth.), European ash (Fraxinus excelsior L.), English oak (Quercus robur L.), small-leaved lime (Tilia cordata Mill.), and white elm (Ulmus laevis Pall).

Research was carried out in 2018 in Trostyanetske Forest Enterprise (Left-bank Forest Steppe; Sumy region). Diameter (DBH), Kraft class, and category of health condition were assessed for each tree. Defoliation, dieback and epicormic shoots occurrence were evaluated as proportion of trees with respective symptoms. Severity of each parameter of tree health condition was estimated using respective scores.

No tree species is defoliated over 50\%. A birch is characterized by the lowest health condition index (1.6) for living trees, dieback (10\%), epicormic shoots occurrence (15.9\%) and recently died trees proportion (0.7\%), but high proportion of trees died over year ago (10.7\%). An oak is characterized by the highest health condition index (2.1), proportion of trees with dieback (45.4\%) and epicormic shoots (21.7\%). Proportion of trees with dieback is 21.5 to $25 \%$ for alder, lime and maple, a bit higher for elm and ash (30.9 and 31.3\% respectively).

$D B H$, Kraft class, and health condition index significantly correlate with health condition parameters of analyzed tree species, but the most of correlations are very slight and slight. Correlation between health condition index and defoliation score is significant, positive and high for all tree species (from 0.78 for alder to 0.9 for birch). Correlation between health condition index and dieback score is positive and significant for all tree species, is slight for ash, birch, lime, and alder, and moderate for maple, oak and elm. Correlation between health condition index and epicormic shoots occurrence is significant and positive for all tree species except birch, but is very slight in all cases except elm, where it is slight.

Key words: diameter (DBH); Kraft class; health condition index; tree mortality; defoliation; dieback; epicormic shoots.

Introduction. Forest health worsening is a great problem in many regions (Matsiakh \& Kramarets, 2014, Davydenko \& Meshkova, 2017, Skovsgaard et al., 2017). Climate change and anthropogenic pressure increase forest susceptibility to damage by fire and injurious organisms (Shvidenko et al., 2017) as well as promote their spread and maintenance in new regions (Denman et al., 2016, Goychuk et al., 2018ab, Jürisoo

Valentyna L. Meshkova - full Member of Forestry Academy of Sciences of Ukraine, Doctor habil. (agricultural sciences), professor, Ukrainian Research Institute of Forestry \& Forest Melioration named after G. M. Vysotsky. Pushkinska str., 86, Kharkiv, 61024, Ukraine. Tel.: +38(097)37194-58. E-mail: Valentynameshkova@gmail.com ORCID: https:// orcid.org/0000-0001-6483-2736

2 Tetiana S. Pyvovar - PhD, Senior Researcher, Ukrainian Research Institute of Forestry \& Forest Melioration named after G. M. Vysotsky. Pushkinska str., 86, Kharkiv, 61024, Ukraine. Tel.: +38(097)358-97-49. E-mail: pyvovartatiana@gmail.com ORCID: https:// orcid.org/00000001-7250-8549

3 Oleksandr V. Tovstukha - PhD, Deputy Chief of Sumy Regional Administration of Forest and Hunting Management. Zasumska str. 12a, Sumy, 40030, Ukraine. Tel. +38(067)540-17-70. E-mail: sekretar@sumylis.gov.ua 
et al., 2019, Kramarets \& Matsiakh, 2018, Meshkova \& Davydenko, 2016).

Tree health assessment is important for maintaining of forest biodiversity, its ecological functions as well for forest management strategy. In managed forests the main purpose of such assessment is selection of trees for sanitation felling before timber losing quality. In unmanaged forests and urban stands, it is necessary to reveal an injurious impact early and to treat (therapy) or to fell in time the trees (for example, with heart rots), which are dangerous for vehicles, personnel and visitors (Skovsgaard et al., 2017, Enderle et al., 2018).

Different scales have been developed for tree health condition assessment by visual characteristics (crown density and color, dead branches presence and proportion etc.) (Tallent-Halsell, 1995, Ferretti, 1998, Innes, 1998, Manual..., 2010). These scales are often the same for different tree species, but sometimes consider their features, particularly in assessment of wet wood or ash dieback.

The species-specific features of Quercus robur L., Fraxinus excelsior L., Acer platanoides L., and Tilia cordata Mill. were revealed by forest monitoring databases analysis. Complex evaluation of forest health has been developed by the data of Level II monitoring accounting crown condition, tree damage and mortality (Pyvovar 2008, 2010). However, given approach did not consider the cases of apparently healthy trees with heart rots inside or possibility to recover for the trees with high dieback level. Research of $F$. excelsior (Meshkova \& Borysova, 2017) and Betula pendula Roth. (Meshkova et al., 2018) in the Left-Bank ForestSteppe allowed considering defoliation, dieback and epicormic shoots occurrence the main parameters of forest health condition, although the prevalence of other symptoms and signs was taking into account.

Our current research continues revealing the most informative parameters of forest health condition evaluation for seven tree species - A. platanoides, Alnus glutinosa (L.) Gaertn, B. pendula, F. excelsior, Q. robur, T. cordata, and Ulmus laevis Pall., which are the most spread in the Left-Bank Forest-Steppe. Particularly in Trostyanetske Forest Enterprise they occupy about $80 \%$ of forested area. Since recent forest inventory (for 2009 to 2018) the proportion of stands with $Q$. robur as the main forest forming species decreased from 65.1 to $61.4 \%$, and proportion of F. excelsior increased from 4.4 to $10 \%$. Proportion of other deciduous tree species increased by less degree (A. glutinosa - from 1.8 to $2.1 \%$, A. platanoides from 1.6 to $2.3 \%$, T. cordata from 0.65 to $0.79 \%, B$. pendula from 1.4 to $1.5 \%$ etc.). Similar situation was reported for other parts of region (Nazarenko \& Babenko, 2015) and connected with decline of vegetative oak stands of the $2^{\text {nd }}$ or $3^{\text {rd }}$ generation.

The aim of research was to evaluate the variability and relations with forest health condition its main parameters (defoliation, dieback and epicormic shoots occurrence) in seven tree species: Norway maple (Acer platanoides L.), black alder (Alnus glutinosa L.), silver birch (Betula pendula Roth.), European ash (Fraxinus excelsior L.), English oak (Quercus robur L.), smallleaved lime (Tilia cordata Mill.), and white elm (Ulmus laevis Pall $)^{l}$.

Objects and methods. Research was carried out in 2018 in Krasnyanske, Lytovske, Makivske, and Neskuchanske forestries of Trostyanetske Forest Enterprise (Left-bank Forest Steppe; Sumy region; $50^{\circ}$ $36 "-50^{\circ} 48^{\prime \prime} \mathrm{N} ; 34^{\circ} 77^{\prime \prime}-34^{\circ} 97^{\prime \prime} \mathrm{E}$; $143-182 \mathrm{~m}$ a.s.1.).

Health condition of over 5000 trees was assessed visually in 129 randomly chosen subcompartments which covered different relief, forest site conditions, and tree species composition. Tree age was from 15 to 140 years, but was not uniform in the most of plots, as vegetative and seed specimens were presented. Therefore, we considered the diameter at breast height (DBH) and Kraft classes as more reliable than age parameters for health condition analysis.

For each inspected tree all visible symptoms and signs of damage were registered, however, only some of them (defoliation, dieback and epicormic shoots occurrence) are analyzed in this paper for seven tree species.

Category of health condition was evaluated on a range of visual characteristics according to «Sanitary rules in the forests of Ukraine» (Sanitary rules..., 1995). Each tree was referred to one of six categories of health condition: $1^{\text {st }}$ - healthy; $2^{\text {nd }}-$ weakened; $3^{\text {rd }}-$ severely weakened; $4^{\text {th }}-$ drying up; $5^{\text {th }}-$ recently died; $6^{\text {th }}-$ died over year ago. Health condition index (HCI) for each tree species was calculated as mean weighted from trees number of each category of health condition.

Defoliation, dieback and epicormic shoots occurrence was evaluated as proportion of trees with respective symptoms. Severity of each parameter of tree health condition was estimated using respective scores.

Crown defoliation and dieback level (proportion of dry branches) was estimated as a percentage and then converted to points: 0 - absent; 1 point - up to $10 \%$; 2 points $-11-50 \% ; 3$ points $-51-75 \%$; 4 points over $75 \%$. Epicormic shoots occurrence was estimated by score: 0 - absent; 1 - single; 2 - multiple; 3 completely covered stem. Considering proportion of trees in different classes, mean weighted severity was evaluated for each parameter of forest health condition.

Tree mortality was expressed as a percentage of dead trees out of the total trees of certain species.

The data for all inspected stands were pooled for each tree species for analysis.

Normality tests, summary statistics, Pearson's correlation, one-way analysis of variance (ANOVA) with Tukey HSD test with a significance level of $\mathrm{p}<0.05$ (Atramentova \& Utevskaya, 2008) were performed using Microsoft Excel applications and statistical software package PAST: Paleontological Statistics Software Package for Education and Data Analysis (Hammer et al., 2001).

Common names and tree genera names are mentioned in the tables, figures, and text below. 
Results and discussion. Among inspected tree species, oak and ash were the main forest forming species in respective subcompartments. Their mean DBH was 34.5 and $33.8 \mathrm{~cm}$ respectively and maximal DBH was 80 and $100 \mathrm{~cm}$ (Fig. 1). Birch ranked the third in DBH (mean $24.2 \mathrm{~cm}$, max $66 \mathrm{~cm}$ ). The rest tree species were much smaller with mean DBH 15.5-19.3 $\mathrm{cm}$ and maximal DBH below $50 \mathrm{~cm}$.

Distribution of trees by DBH was corresponded to species composition of certain stands and trees distribution by Kraft classes. All analyzed tree species were characterized from 1 to $4 \mathrm{Kraft}$ class in different stands, and alder and lime even to 5 Kraft class (Fig. 2).

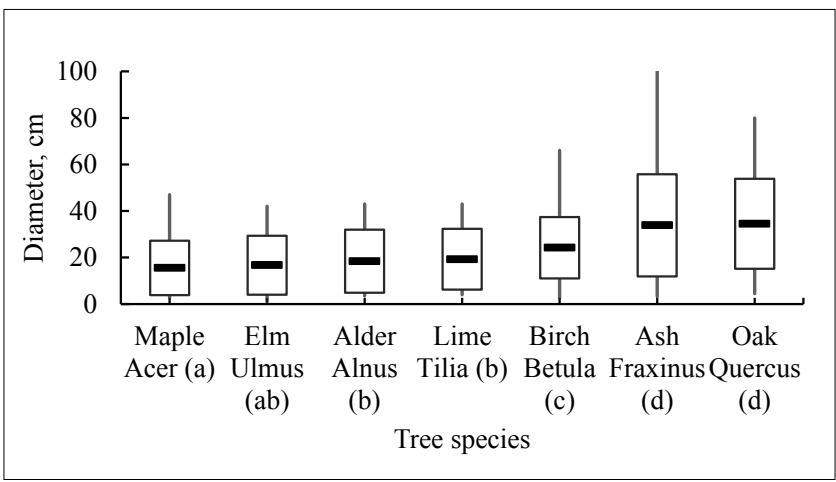

Fig. 1. Diameter of deciduous trees in inspected stands of Trostyanetske Forest Enterprise (tree species followed different letters in brackets are significantly different at the $95 \%$ confidence level)

Oak, ash and birch are characterized by the best growth with mean Kraft class 1.4, because they were more often the forest forming species. Mean Kraft class increased from 2 for alder to 2.2, 2.4 and 2.7 for lime, elm, and maple respectively (see Fig. 2). The last three species grow mainly in mixed stands and their growth depends on neighboring tree species.

All analyzed tree species were characterized from 1 to 4 category of health condition in different stands (Fig. 3). The best health condition of living trees (1.6) was assessed for birch. Mean health condition of the most of rest tree species was about 2 (1.9-2.0), but was significantly higher for oak (2.1)

Recently died trees of maple, lime, alder and elm were not revealed by our inspection (Tab. 1).

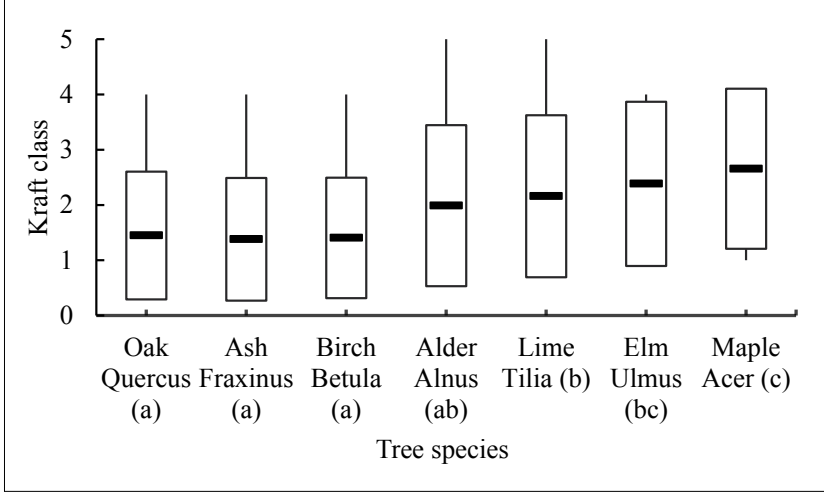

Fig. 2. Kraft class of deciduous trees in inspected stands of Trostyanetske Forest Enterprise (tree species followed different letters in brackets are significantly different at the $95 \%$ confidence level)

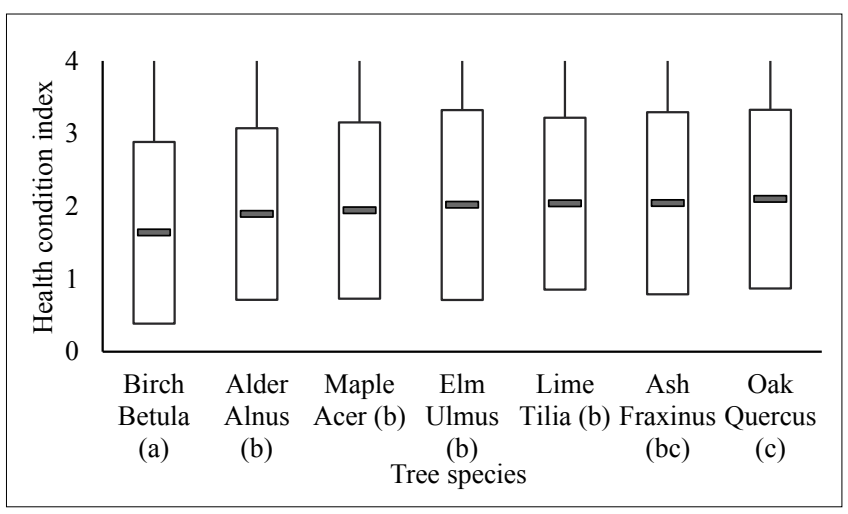

Fig. 3. Health condition index of deciduous trees in inspected stands of Trostyanetske Forest Enterprise (tree species followed different letters in brackets are significantly different at the $95 \%$ confidence level; only living trees are considered)

Proportion of recently died trees was $0.1 \%$ for ash and $0.7 \%$ for birch and oak. The trees of the $6^{\text {th }}$ category (died over year ago) were revealed for all species except oak. Such proportion increased from $0.1 \%$ and $0.7 \%$ for ash, acer and lime to $3.5 \%$ for elm and $10.7 \%$ for birch (see Tab. 1). The causes of high birch mortality in previous years will be studied further.

Defoliation was the most expressed health condition parameter (Tab. 2).

Table 1

Mortality of deciduous trees in inspected stands of Trostyanetske Forest Enterprise, \%

\begin{tabular}{lccccccc}
\hline \multirow{2}{*}{ Number of dead trees ** } & \multicolumn{7}{c}{ Proportion of trees, \% \pm SE * } \\
\cline { 2 - 8 } & $\begin{array}{c}\text { Birch } \\
\text { Betula } \\
(1236)\end{array}$ & $\begin{array}{c}\text { Maple } \\
\text { Acer } \\
(796)\end{array}$ & $\begin{array}{c}\text { Ash } \\
\text { Fraxinus } \\
(1016)\end{array}$ & $\begin{array}{c}\text { Lime } \\
\text { Tilia } \\
(300)\end{array}$ & $\begin{array}{c}\text { Alder } \\
\text { Alnus } \\
(389)\end{array}$ & $\begin{array}{c}\text { Elm } \\
\text { Ulmus } \\
(57)\end{array}$ & $\begin{array}{c}\text { Oak } \\
\text { Quercus } \\
(153)\end{array}$ \\
\hline $5^{\text {th }}$ category of health condition - & $0.7 \pm$ & $0.0 \mathrm{a}$ & $0.1 \pm$ & $0.0 \mathrm{a}$ & $0.0 \mathrm{a}$ & $0.0 \mathrm{a}$ & $0.7 \pm$ \\
recently died & $0.24 \mathrm{c}$ & & $0.10 \mathrm{~b}$ & & $0.65 \mathrm{~d}$ \\
$6^{\text {th }}$ category of health condition - & $10.7 \pm$ & $0.4 \pm$ & $0.1 \pm$ & $0.7 \pm$ & $1.5 \pm$ & $3.5 \pm$ & $0.0 \mathrm{a}$ \\
died over year ago & $0.88 \mathrm{f}$ & $0.22 \mathrm{c}$ & $0.10 \mathrm{~b}$ & $0.47 \mathrm{~d}$ & $0.62 \mathrm{e}$ & $2.44 \mathrm{~g}$ & \\
\multirow{2}{*}{ All dead trees } & $11.4 \pm$ & $0.4 \pm$ & $0.2 \pm$ & $0.7 \pm$ & $1.5 \pm$ & $3.5 \pm$ & $0.7 \pm$ \\
& $0.90 \mathrm{e}$ & $0.22 \mathrm{~b}$ & $0.14 \mathrm{a}$ & $0.47 \mathrm{c}$ & $0.62 \mathrm{~d}$ & $2.44 \mathrm{f}$ & $0.65 \mathrm{~d}$ \\
\hline
\end{tabular}

* Number of all trees by species in brackets;

**Means followed by different letters in each row are significantly different at the $95 \%$ confidence level. 


\section{Proportion of deciduous trees with certain health condition parameters in inspected stands} of Trostyanetske Forest Enterprise

\begin{tabular}{|c|c|c|c|c|c|c|c|}
\hline \multirow[b]{2}{*}{$\begin{array}{l}\text { Parameters of health } \\
\text { condition } * *\end{array}$} & \multicolumn{7}{|c|}{ Proportion of trees, $\% \pm \mathrm{SE}^{*}$} \\
\hline & $\begin{array}{l}\text { Birch } \\
\text { Betula } \\
(1236)\end{array}$ & $\begin{array}{l}\text { Maple } \\
\text { Acer } \\
(796)\end{array}$ & $\begin{array}{c}\text { Ash } \\
\text { Fraxinus } \\
\text { (1016) }\end{array}$ & $\begin{array}{c}\text { Lime } \\
\text { Tilia } \\
(300)\end{array}$ & $\begin{array}{l}\text { Alder } \\
\text { Alnus } \\
(389)\end{array}$ & $\begin{array}{l}\text { Elm } \\
\text { Ulmus } \\
(57)\end{array}$ & $\begin{array}{c}\text { Oak } \\
\text { Quercus } \\
(153)\end{array}$ \\
\hline Defoliation & $42.2 \pm 1.40 \mathrm{a}$ & $\begin{array}{l}67.2 \\
\pm 1.66 \mathrm{~b}\end{array}$ & $\begin{array}{c}68,3 \\
\pm 1.46 \mathrm{~b}\end{array}$ & $\begin{array}{c}73.8 \\
\pm 2.54 \mathrm{~b}\end{array}$ & $\begin{array}{c}72.8 \\
\pm 2.26 \mathrm{~b}\end{array}$ & $\begin{array}{c}69.1 \\
\pm 6.12 \mathrm{~b}\end{array}$ & $\begin{array}{c}73.0 \\
\pm 3.59 \mathrm{~b}\end{array}$ \\
\hline Dieback & $10.0 \pm 0.85 \mathrm{a}$ & $\begin{array}{l}25.0 \\
\pm 1.53 \mathrm{~b}\end{array}$ & $\begin{array}{l}31.3 \\
\pm 1.45 \mathrm{c}\end{array}$ & $\begin{array}{c}24.5 \\
\pm 2.48 \mathrm{~b}\end{array}$ & $\begin{array}{l}21.5 \\
\pm 2.08 \mathrm{~b}\end{array}$ & $\begin{array}{c}30.9 \\
\pm 6.12 \mathrm{c}\end{array}$ & $\begin{array}{c}45.4 \\
\pm 4.03 \mathrm{~d}\end{array}$ \\
\hline Epicormic shoots & $15.9 \pm 1.04 \mathrm{a}$ & $\begin{array}{l}16,5 \\
\pm 1.32 \mathrm{a}\end{array}$ & $\begin{array}{c}19.4 \\
\pm 1.24 \mathrm{a}\end{array}$ & $\begin{aligned} & 15.8 \\
\pm & 2.10 \mathrm{a}\end{aligned}$ & $\begin{aligned} & 17.6 \\
\pm & 1.93 \mathrm{a}\end{aligned}$ & $\begin{array}{c}25.5 \\
\pm 5.77 \mathrm{~b}\end{array}$ & $\begin{array}{c}21.7 \\
\pm 3.33 \mathrm{~b}\end{array}$ \\
\hline
\end{tabular}

* Number of trees in brackets;

**Means followed by different letters in each row are significantly different at the $95 \%$ confidence level.

In analyzed stands defoliation was mainly the consequence of foliage underdevelopment in unfavorable conditions or in weakened stands and less often the result of insect damage. The share of trees with defoliation over $0 \%$ was the lowest for birch $(42.2 \%)$ and significantly higher $(67.2-73.8 \%)$ for the rest tree species (Tab. 3).

At the same time defoliation up to $10 \%$ (score 1) was difficult to identify (besides alder and birch), and any species was defoliated over $50 \%$ (score 3 ). The birch trees were the most represented $(57.8 \%)$ in the lowest class of defoliation severity (absence of defoliation), but rather large proportion of them had defoliation $11-50 \%$ (class 2). About $30 \%$ of maple, ash and elm trees (31.7-32.8\%) were not defoliated at all, and about $70 \%$ of these species were characterized with defoliation $11-50 \%$ (class 2). At last below 30\% of lime, alder and oak trees were not defoliated at all. Over $70 \%$ of lime and oak belonged to the 2 defoliation class, and alder trees were represented by $1(7 \%)$ and 2 (65.8\%) defoliation class (see Tab. 3).

The share of trees with dieback was the lowest for birch $(10 \%)$. It was 21.5 to $25 \%$ for alder, lime and maple, a bit higher for elm and ash (30.9 and 31.3\%) and the highest for oak (45.4\%) (see Tab. 2).

The highest part of trees without dieback (class $0-$ $90.1 \%$ ) was revealed for birch (see Tab. 3). Dieback was absent in $75-78.5 \%$ of maples, limes and alders, 68.7 and $69.1 \%$ of ashes and elms respectively, and only $54.6 \%$ oaks. Proportion of trees of each analyzed species decreased from 0 to 3 classes of dieback severity score. Proportion of trees with dieback severity 51$75 \%$ was the highest for elm (3.6\%) and oak (2.6\%), and total amount of trees with dieback severity over $10 \%$ was 14.5 and $15.1 \%$ for elm and oak respectively. Such situation can be connected both by certain damage factor influence and by ability of these species to recover the crown, which must be studied further.

Proportion of trees with epicormic shoots was rather close for most of analyzed tree species (15.8$19.4 \%)$ and was significantly higher for oak and elm (21.7 and $25.5 \%$ respectively) (see Tab. 2). It means that the trees with the highest dieback recover crowns in greater degree.

Considering epicormic shoots occurrence by classes shows the highest proportion of trees in class $\ll 0 »$ (absence of epicormic shoots), rather low proportion of trees in class « 2 » (multiple epicormic shoots) and any tree in class «3» (see Tab. 3). The lowest proportion of trees with epicormic shoots in class «1» (single epicormic shoots) is registered for birch, maple, and lime (15.5-15.8\%). This value is a bit higher for alder, ash and oak (14.6-21.7\%) and is the highest for elm (23.7\%). Mean weighted class of epicormic shoots occurrence is the lowest for birch and lime (0.16), is a bit higher for maple, acer and ash $(0.18-0.20)$, and the highest for oak and elm $(0.22$ and 0.27 respectively).

Pairwise analysis of individual health condition parameters shows significant and negative correlation of DBH with health condition index for birch, ash and lime (Tab. 4). It indicates the better health condition of largest trees, although correlation coefficient is very slight.

Correlation of Kraft class with DBH is significant and negative for all tree species (Tab. 4), which is correct by definition, with the highest correlation index for maple (-0.71) and lime (-0.63) and the lowest for elm and alder (-0.43 and -0.46 respectively).

Correlation of DBH with defoliation score is significant and negative and very slight for ash, oak and birch, with dieback score - is significant and negative only for birch and is very slight, with epicormic shoots occurrence - is significant and negative for ash and positive for alder, but is very slight in both cases.

Significant positive correlation of health condition index with Kraft class is evaluated for all inspected tree species except oak. It is very slight for ash and slight for alder, birch and elm. Significant positive slight correlation of Kraft class with defoliation is evaluated for alder, maple and oak, between Kraft class and dieback score it is very slight for oak, between Kraft class and epicormic shoots occurrence it is very slight negative for ash and positive for elm. 
Correlation between health condition index with defoliation score is significant, positive and high for all analyzed tree species (from 0.78 for alder to 0.9 for birch), with dieback score - is positive and significant for all tree species, particularly slight for ash, birch, lime, and alder, and moderate for maple, oak and elm. Correlation between health condition index and epicormic shoots occurrence is significant and positive for all analyzed tree species except birch, but is very slight in all cases except elm, where it is slight.

\section{Proportion of trees in different classes of health condition parameters in inspected stands of Trostyanetske Forest Enterprise}

Table 3

\begin{tabular}{|c|c|c|c|c|c|}
\hline \multirow{2}{*}{ Tree species** } & \multicolumn{4}{|c|}{ Proportion of trees in different classes, $\% \pm \mathrm{SE}^{*}$} & \multirow{2}{*}{$\begin{array}{l}\text { Mean weighted } \\
\text { class }\end{array}$} \\
\hline & 0 & 1 & 2 & 3 & \\
\hline & \multicolumn{5}{|c|}{ Defoliation } \\
\hline Birch Betula & $57.8 \pm 1.49 \mathrm{a}$ & $0.2 \pm 0.13 b$ & $42.0 \pm 1.49 \mathrm{a}$ & 0.0 & 0.84 \\
\hline Maple Acer & $32.8 \pm 1.67 \mathrm{~b}$ & $0.0 \mathrm{a}$ & $67.2 \pm 1.67 b$ & 0.0 & 1.34 \\
\hline Ash Fraxinus & $31.7 \pm 1.46 b$ & $0.0 \mathrm{a}$ & $68.3 \pm 1.46 b$ & 0.0 & 1.37 \\
\hline Lime Tilia & $26.2 \pm 2.55 \mathrm{c}$ & $0.0 \mathrm{a}$ & $73.8 \pm 2.55 \mathrm{c}$ & 0.0 & 1.48 \\
\hline Alder Alnus & $27.2 \pm 2.30 \mathrm{c}$ & $7.0 \pm 1.30 \mathrm{c}$ & $65.8 \pm 2.40 \mathrm{~b}$ & 0.0 & 1.39 \\
\hline Elm Ulmus & $32.7 \pm 6.20 b$ & $0.0 \mathrm{a}$ & $67.3 \pm 6.30 b$ & 0.0 & 1.35 \\
\hline \multirow[t]{2}{*}{ Oak Quercus } & $27.0 \pm 3.60 \mathrm{c}$ & $0.0 \mathrm{a}$ & $73.0 \pm 3.60 \mathrm{c}$ & 0.0 & 1.46 \\
\hline & \multicolumn{5}{|c|}{ Dieback } \\
\hline Birch Betula & $90.1 \pm 0.90 \mathrm{a}$ & $5.7 \pm 0.70 \mathrm{a}$ & $3.8 \pm 0.59 \mathrm{a}$ & $0.4 \pm 0.18 \mathrm{a}$ & 0.15 \\
\hline Maple Acer & $75.0 \pm 1.54 b$ & $17.8 \pm 1.36 \mathrm{~b}$ & $5.4 \pm 0.80 \mathrm{~b}$ & $1.8 \pm 0.47 \mathrm{~b}$ & 0.34 \\
\hline Ash Fraxinus & $68.7 \pm 1.46 \mathrm{c}$ & $23.1 \pm 1.32 \mathrm{c}$ & $6.9 \pm 0.80 \mathrm{c}$ & $1.3 \pm 0.35 b$ & 0.41 \\
\hline Lime Tilia & $75.5 \pm 2.49 b$ & $19.1 \pm 2.28 b$ & $4.4 \pm 1.18 \mathrm{ab}$ & $1.0 \pm 0.58 \mathrm{ab}$ & 0.31 \\
\hline Alder Alnus & $78.5 \pm 2.10 b$ & $17.4 \pm 1.90 b$ & $3.3 \pm 0.90 \mathrm{a}$ & $0.8 \pm 0.40 \mathrm{a}$ & 0.26 \\
\hline Elm Ulmus & $69.1 \pm 6.20 \mathrm{c}$ & $16.4 \pm 5.00 \mathrm{~b}$ & $10.9 \pm 4.20 \mathrm{~d}$ & $3.6 \pm 2.50 \mathrm{~d}$ & 0.49 \\
\hline \multirow[t]{2}{*}{ Oak Quercus } & $54.6 \pm 4.00 \mathrm{~d}$ & $30.3 \pm 3.70 \mathrm{~d}$ & $12.5 \pm 2.70 \mathrm{~d}$ & $2.6 \pm 1.30 \mathrm{bc}$ & 0.63 \\
\hline & \multicolumn{5}{|c|}{ Epicormic shoots occurrence } \\
\hline Birch Betula & $84.1 \pm 1.10 \mathrm{a}$ & $15.8 \pm 1.10 \mathrm{a}$ & $0.1 \pm 0.09 \mathrm{~b}$ & 0.0 & 0.16 \\
\hline Maple Acer & $83.5 \pm 1.32 \mathrm{a}$ & $15.5 \pm 1.29 a$ & $1.0 \pm 0.35 b$ & 0.0 & 0.18 \\
\hline Ash Fraxinus & $80.6 \pm 1.24 \mathrm{ab}$ & $19.2 \pm 1.24 b$ & $0.2 \pm 0.14 \mathrm{~b}$ & 0.0 & 0.20 \\
\hline Lime Tilia & $84.2 \pm 2.11 \mathrm{a}$ & $15.8 \pm 2.11 \mathrm{a}$ & $0.0 \mathrm{a}$ & 0.0 & 0.16 \\
\hline Alder Alnus & $82.4 \pm 1.90 \mathrm{ab}$ & $17.6 \pm 1.90 \mathrm{ab}$ & $0.0 \mathrm{a}$ & 0.0 & 0.18 \\
\hline Elm Ulmus & $74.5 \pm 5.90 \mathrm{~b}$ & $23.7 \pm 5.70 b c$ & $1.8 \pm 1.80 \mathrm{~b}$ & 0.0 & 0.27 \\
\hline Oak Quercus & $78.3 \pm 3.30 b$ & $21.7 \pm 3.30 \mathrm{~b}$ & $0.0 \mathrm{a}$ & 0.0 & 0.22 \\
\hline
\end{tabular}

*Defoliation and dieback classes: 0 - absent; 1 - up to $10 \% ; 2-11-50 \% ; 3-51-75 \%$; $4-$ over $75 \%$ of foliage absent or dry branches respectively. Epicormic shoots occurrence classes: 0 - absent; 1 - single; 2 - multiple; 3 - completely covered stem.

**Means followed by different letters in each column for each health condition parameter are significantly different at the $95 \%$ confidence level.

Correlation between different health condition parameters for different tree species

Table 4

\begin{tabular}{lcccccccc}
\hline \multirow{1}{*}{ Tree species } & \multicolumn{8}{c}{ Correlation index } \\
\cline { 2 - 8 } & $\begin{array}{c}\text { DBH }- \\
\text { HCI }\end{array}$ & $\begin{array}{c}\text { DBH }- \\
\text { KC }\end{array}$ & $\begin{array}{c}\text { DBH }- \\
\text { DEF }\end{array}$ & $\begin{array}{c}\text { DBH }- \\
\text { DB }\end{array}$ & $\begin{array}{c}\text { DBH }- \\
\text { ES }\end{array}$ & $\begin{array}{c}\text { HCI }- \\
\text { KC }\end{array}$ & $\begin{array}{c}\text { HCI }- \\
\text { DEF }\end{array}$ & $\begin{array}{c}\text { HCI }- \\
\text { DB }\end{array}$ \\
\hline Birch Betula (1236) & $-0.24^{*}$ & $-0.54^{*}$ & $-0.26^{*}$ & $-0.10^{*}$ & -0.05 & $0.35^{*}$ & $0.90^{*}$ & $0.43^{*}$ \\
Maple Acer (796) & -0.05 & $-0.71^{*}$ & 0.02 & 0.03 & -0.02 & $0.16^{*}$ & $0.81^{*}$ & $0.53^{*}$ \\
Ash Fraxinus (1016) & $-0.15^{*}$ & $-0.53^{*}$ & $-0.14^{*}$ & -0.03 & $-0.18^{*}$ & $0.08^{*}$ & $0.85^{*}$ & $0.39^{*}$ \\
Lime Tilia (300) & $-0.13^{*}$ & $-0.63^{*}$ & -0.06 & -0.04 & 0.07 & $0.26^{*}$ & $0.78^{*}$ & $0.47^{*}$ \\
Alder Alnus (389) & -0.08 & $-0.46^{*}$ & -0.04 & -0.02 & $0.16^{*}$ & $0.37^{*}$ & $0.79^{*}$ & $0.46^{*}$ \\
Elm Ulmus (57) & 0.05 & $-0.43^{*}$ & -0.14 & -0.03 & 0.20 & $0.34^{*}$ & $0.82^{*}$ & $0.62^{*}$ \\
Oak Quercus (153) & -0.12 & $-0.56^{*}$ & $-0.17^{*}$ & 0.08 & -0.09 & -0.05 & $0.82^{*}$ & $0.55^{*}$ \\
\hline
\end{tabular}


Table 4 continuation

\begin{tabular}{lccccccc}
\hline \multirow{2}{*}{ Tree species } & \multicolumn{7}{c}{ Correlation index } \\
\cline { 2 - 7 } & HCI - ES & KC - DEF & KC - DB & KC - ES & DEF - DB & DEF - ES & DB - ES \\
\hline Birch Betula (1236) & 0,07 & $0,36^{*}$ & $0,16^{*}$ & 0,06 & $0,28^{*}$ & 0,07 & $0,12^{*}$ \\
Maple Acer (796) & $0,27^{*}$ & 0,06 & 0,02 & $-0,01$ & $0,31^{*}$ & $0,25^{*}$ & $0,22^{*}$ \\
Ash Fraxinus (1016) & $0,22^{*}$ & 0,03 & 0,07 & $0,11^{*}$ & $0,34^{*}$ & $0,22^{*}$ & $0,12^{*}$ \\
Lime Tilia (300) & $0,19^{*}$ & $0,15^{*}$ & 0,06 & $-0,04$ & $0,28^{*}$ & $0,13^{*}$ & 0,02 \\
Alder Alnus (389) & $0,16^{*}$ & $0,24^{*}$ & 0,08 & $-0,01^{*}$ & $0,28^{*}$ & $0,13^{*}$ & 0,0004 \\
Elm Ulmus (57) & $0,34^{*}$ & $0,49^{*}$ & 0,19 & 0,09 & $0,48^{*}$ & $0,33^{*}$ & 0,07 \\
Oak Quercus (153) & $0,29^{*}$ & $-0,03$ & $-0,14$ & 0,09 & $0,44^{*}$ & $0,32^{*}$ & 0,12 \\
\hline
\end{tabular}

* DBH - tree diameter on $1.3 \mathrm{~m}$; HCI - health condition index; DEF - defoliation score; DB - dieback score; ES - epicormic shoots occurrence score; KC - Kraft class; significant correlations are marked with an asterisk;

** Number of trees in brackets

Correlation between defoliation and dieback score is positive and significant for all analyzed tree species but is very slight for birch, lime and alder most of them and slight for other tree species. The highest correlation coefficients, although also slight are evaluated for oak and elm ( 0.44 and 0.48 respectively).

Correlation between defoliation and epicormic shoots occurrence is significant and positive for all analyzed tree species, but very slight for most of them and slight for oak and elm (0.32 and 0.33 respectively).

Correlation between dieback and epicormic shoots occurrence is significant, positive and slight only for ash, birch and maple (0.12-0.22) (see Tab. 4).

Considering rather slight correlation between the most of analyzed health condition parameters we counted the total score by summarizing scores for defoliation, dieback and epicormic shoots occurrence (Fig. 4).

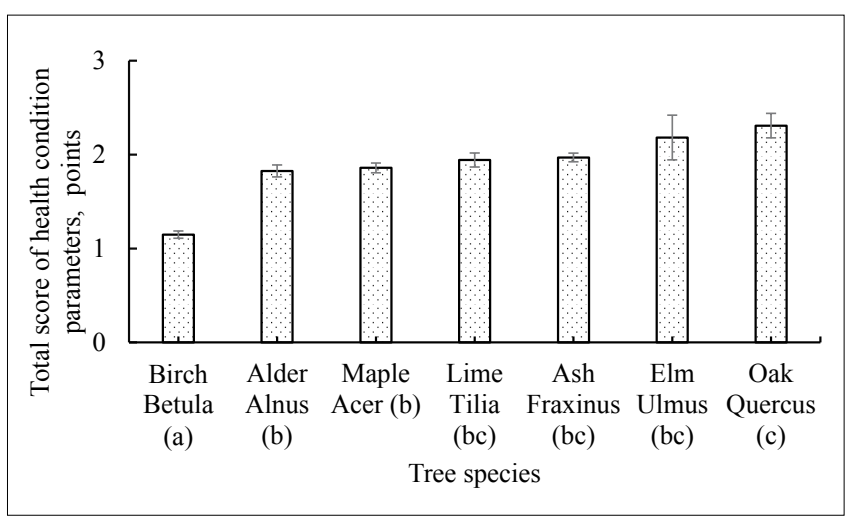

Fig. 4. Total score of health condition parameters for deciduous trees in inspected stands of Trostyanetske Forest Enterprise (tree species followed different letters in brackets are significantly different at the $95 \%$ confidence level)

The order of tree species by total score (see Fig. 4) is close to those by health condition index (see Fig. 3) with an elm as exclusion. However, the difference of the both parameters between elm, lime and ash is not significant.
Thus analysis of the main visible parameters of health condition of trees in the deciduous stands of Trostyanetske Forest Enterprise shows, that all studied tree species are weakened with the best health condition of birch and the poorest condition of elm and oak. However, heart rots and other types of stem and root damage were not involved into this analysis which can bring some correction to conclusion.

Conclusions. Among inspected deciduous tree species of Trostyanetske Forest Enterprise no one is defoliated over $50 \%$. A birch is characterized by the lowest health condition index (1.6) for living trees, dieback $(10 \%)$, epicormic shoots occurrence $(15.9 \%)$ and recently died trees proportion $(0.7 \%)$, but high proportion of trees died over year ago (10.7\%). An oak is characterized by the highest health condition index (2.1), proportion of trees with dieback $(45.4 \%)$ and epicormic shoots $(21.7 \%)$. Proportion of trees with dieback is 21.5 to $25 \%$ for alder, lime and maple, a bit higher for elm and ash (30.9 and 31.3\%).

Diameter (DBH), Kraft class, and health condition index significantly correlate with health condition parameters of analyzed tree species, but the most of correlations are very slight and slight. Correlation of DBH with health condition parameters is mostly negative, other correlations are positive.

Correlation between health condition index and defoliation score is significant, positive and high for all analyzed tree species (from 0.78 for alder to 0.9 for birch). Correlation between health condition index and dieback score is positive and significant for all analyzed tree species, particularly slight for ash, birch, lime, and alder, and moderate for maple, oak and elm. Correlation between health condition index and epicormic shoots occurrence is significant and positive for all analyzed tree species except birch, but is very slight in all cases except elm, where it is slight.

Acknowlegements. We would like to thank Dr. Y. Skrylnik, Dr. O. Zinchenko, Dr. I. Sokolova (Ukrainian Research Institute of Forestry \& Forest Melioration named after G.M. Vysotsky), 
Dr. M. Didenko, V. Borysova and Y. Koshelyaeva (Kharkiv National Agrarian University named after V. V. Dokuchaev) for participation in field assessment, and Prof. V. Pasternak for useful and constructive recommendations and text revision.

\section{References}

Atramentova, L.A., \& Utevskaya, O.M. (2008). Statistical methods in biology. Gorlovka (in Russian).

Davydenko, K., \& Meshkova, V. (2017). The current situation concerning severity and causes of ash dieback in Ukraine caused by Hymenoscyphus fraxineus. Dieback of European Ash (Fraxinus spp.), SLU, 220-227.

Denman, S., Barrett, G., Kirk, S.A., McDonald, J.E., \& Coetzee, M.P. (2016). Identification of Armillaria species on declined oak in Britain: implications for oak health. Forestry: An International Journal of Forest Research, 1-14. Forestry 2017; 90, 148-161, doi:10.1093/forestry/cpw054.

Enderle, R., Metzler, B., Riemer, U., \& Kändler, G. (2018). Ash dieback on sample points of the National forest inventory in south-western Germany. Forests, 9 (1), 25. https://doi.org/10.3390/f9010025

Ferretti, M. (1998). Potential and limitation of visual indices of tree condition. Chemosphere, 36 (4-5), 1031-1036. doi:10.1016/s0045-6535(97)10167-9

Goychuk, A., Drozda, V., \& Kulbanska, I. (2018a). Tuberculosis of ash-trees in Western Podillya of Ukraine: etiology, symptomatology and pathogenesis. Proceedings of the Forestry Academy of Sciences of Ukraine, 16, 31-40. https://doi.org/10.15421/411804

Goychuk, A., Drozda, V., \& Shvets, M. (2018b). Risk of birch disappearance in Zhytomyr Polissya of Ukraine. Proceedings of the Forestry Academy of Sciences of Ukraine, 17, 16-25. https://doi. org/10.15421/411816

Hammer, O., Harper, D.A. T., \& Ryan, P. D. (2001). PAST: paleontological statistics software package for education and data analysis. Palaeontologia Electronica, 4, 1-9.

Innes, J.L. (1998). An assessment of the use of crown structure for the determination of the health of beech (Fagus sylvatica). Forestry: An International Journal of Forest Research, 71 (2), 113-130.

Jürisoo, L., Adamson, K., Padari, A., \& Drenkhan, R. (2019). Health of elms and Dutch elm disease in Estonia. European Journal of Plant Pathology, 1-19. https://doi.org/10.1007/s10658-019-01707-0

Kramarets, V., \& Matsiakh, I. (2018). The role of biotic factors in spruce decline in the Ukrainian Carpathians. Proceedings of the Forestry Academy of Sciences of Ukraine, 17, 121-132. https://doi. org/10.15421/411827

Manual on methods and criteria for harmonized sampling, assessment, monitoring anand analysis of the effects of air pollution on forests. UNECE, UNECE ICP Forests, Hamburg, 2010. ISBN: 978-
3-926301-03-1. [http://www.icpforests.org/Manual. $\mathrm{htm}]$

Matsiakh, I.P., \& Kramarets, V.O. (2014). Declining of Common Ash (Fraxinus excelsior L.) in Western Ukraine. Scientific Herald of National Forest Technical University of Ukraine, 24.7, 67-74 (in Ukrainian).

Meshkova, V.L., \& Borysova, V.L. (2017). Damage causes of European ash in the permanent sampling plots in Kharkiv region. Forestry and Forest Melioration: 131, 179-186.

Meshkova, V.L., \& Davydenko, K.V. (2016). Verticillium wilt on Norway maple (Acer platanoides L.) in the East of Ukraine. Proceedings of the Forestry Academy of Sciences of Ukraine, 14, 174-179.

Meshkova, V. L., Koshelyaeva, Y.V., Skrylnik, Y.Y., \& Zinchenko, O.V. (2018). Symptoms and signs of Silver birch damage and injury in Dergachivske forestry. The Bulletin of Kharkiv National Agrarian University. Series "Phytopathology and Entomology», 1-2, 101-110 (in Ukrainian)

Nazarenko, V.V., \& Babenko, V.V. (2015). The state and dynamics of the forestry fund Skryapaivsky educational-research forestry. Scientific bulletin of Ukrainian National Forestry University, 25 (8), 100105 (in Ukrainian).

Pyvovar, T.S. (2008). Limits of natural variation of crown condition indices for tree species. Forestry and Forest Melioration, 112, 208-217 (in Ukrainian).

Pyvovar T. S. (2010). Complex assessment of forest health by complex of forest monitoring indices. Forestry and Forest Melioration, 117, 99-105 (in Ukrainian).

Sanitary rules in the forests of Ukraine (1995). Kyiv: Ministry of Forest management of Ukraine. 19 p. (in Ukrainian).

Shvidenko, A., Buksha, I., Krakovska, S., \& Lakyda, P. (2017). Vulnerability of Ukrainian forests to climate change. Sustainability, 9 (7), 1152. https://doi. org/10.3390/su9071152

Skovsgaard, J.P., Wilhelm, G. J., Thomsen, I.M., Metzler, B., Kirisits, T., Havrdová, L., ..., \& Clark, J. (2017). Silvicultural strategies for Fraxinus excelsior in response to dieback caused by Hymenoscyphus fraxineus. Forestry: An International Journal of Forest Research, 90 (4), 455-472. https://doi. org/10.1093/forestry/cpx012

Tallent-Halsell, N. G. (ed.) (1995). Forest Health Monitoring. Field Methods Guide. - EPA/620/R 94/027/ U.S. Unviron. Protect. Agency: Washington D.C. 


\section{Параметри санітарного стану листяних порід у лісових насадженнях ДП «Тростянецьке лісове господарство»}

\section{В.Л. Мєшкова' ', Т.С. Пивовар², О. В. Товстуха}

Оцінювання санітарного стану дерев $\epsilon$ важливим аспектом у підтриманні лісового біорізноманіття, екологічних функцій лісу та розвитку стратегії ведення лісового господарства.

Мета досліджень полягала в оцінюванні варіювання та зв'язків із санітарним станом насаджень його основних параметрів (дефоліації, периферійного відмирання крони та поширення водяних пагонів) у семи деревних видів - Acer platanoides L., Alnus glutinosa L., Betula pendula Roth., Fraxinus excelsior L., Quercus robur L., Tilia cordata Mill. та Ulmus laevis Pall.

Дослідження здійснені у 2018 р. у ДП «Тростянецьке ЛГ» (Лівобережний Лісостеп; Сумська область) у 129 рандомізовано вибраних виділах. Для кожного обстеженого дерева оцінювали діаметр на висоті грудей, клас за Крафтом, категорію санітарного стану, дефоліацію, периферійне відмирання крони та поширення водяних пагонів. Поширеність дефоліації, периферійного відмирання крон і водяних пагонів визначали як частку дерев із наявністю відповідних симптомів. Інтенсивність прояву кожного параметра оцінювали за відповідними шкалами.

Жодна порода не була дефолійована більше, ніж на $50 \%$. Береза характеризується найменшими значеннями індексу санітарного стану $(\mathrm{I}, 6)$ для життєздатних дерев, периферійного відмирання крон $(10 \%)$, поширення водяних пагонів $(15,9 \%)$ i частки свіжого сухостою $(0,7 \%)$, однак високою часткою дерев старого сухостою (10,7\%). Дуб характеризується найбільшими значеннями індексу санітарного стану (II,1), частки дерев із наявністю периферійного відмирання крони $(45,4 \%)$ та водяних пагонів (21,7\%). Частка дерев вільхи, липи та клена 3 наявністю периферійного відмирання кро-

Мєшкова Валентина Львівна - дійсний член Лісівничої академії наук України, доктор сільськогосподарських наук, професор, Український науково-дослідний інститут лісового господарства та агролісомеліорації ім. Г.М. Висоцького, вул. Пушкінська, 86, Харків, 61024, Україна. Тел.: +38(097)37194-58. E-mail: Valentynameshkova@gmail.com ORCID: https:// orcid.org/0000-0001-6483-2736

Пивовар Тетяна Сергї̈вна - кандидат сільськогосподарських наук, старший науковий співробітник, Український науково-дослідний інститут лісового господарства та агролісомеліорації ім. Г.М. Висоцького, вул. Пушкінська, 86, Харків, 61024, Україна. Тел.: +38(097)358-97-49. E-mail: pyvovartatiana@gmail.com ORCID: https:// orcid.org/00000001-7250-8549

Товстуха Олександр Володимирович - кандидат сільськогосподарських наук, заступник начальника Сумського обласного управління лісового та мисливського господарства. Засумська вул. 12а, Суми, 40030, Україна. Тел. +38(067)540-17-70. E-mail: sekretar@sumylis.gov.ua ни становила від 21,5 до $25 \%$ і була дещо більшою для в'яза та ясена (30,9 і 31,3\% відповідно).

Діаметр стовбурів, клас за Крафтом та індекс санітарного стану дерев значуще корелює з параметрами санітарного стану відповідних видів, але більшість зв'язків є дуже слабкими та слабкими. Коефіцієнти кореляції між діаметром і параметрами санітарного стану дерев переважно від'ємні, а між рештою параметрів - додатні.

Кореляція між індексом санітарного стану дерев і рівнем дефоліації $є$ значущою, додатною та високою для всіх аналізованих видів дерев (від 0,78 для вільхи до 0,9 для берези). Кореляція між індексом санітарного стану та рівнем периферійного відмирання крони $\epsilon$ додатною та значущою для всіх аналізованих видів дерев, зокрема слабка для ясена, берези, липи та вільхи і помірна - для клена, дуба та в'яза. Кореляція між індексом санітарного стану і поширенням водяних пагонів $є$ значущою та додатною для всіх аналізованих видів дерев, окрім берези, але є дуже слабкою в усіх випадках, окрім в'яза, де вона є слабкою.

Ключові слова: діаметр (діаметр на висоті грудей); клас за Крафтом; індекс санітарного стану; відпад дерев; дефоліація; периферійне відмирання крони; водяні пагони.

\section{Параметры санитарного состояния лиственных пород в лесных насаждениях ГП «Тростянецкое лесное хозяйство»}

\section{В.Л. Мешкова' ${ }^{1}$ Т.С. Пивовар², А. В. Товстуха}

Оценка санитарного состояния деревьев важна для поддержания лесного биоразнообразия, экологических функций леса и развития стратегии ведения лесного хозяйства.

Целью исследований была оценка варьирования и тесноты связей с санитарным состоянием насаждений его основных параметров (дефолиации, пе-

Мешкова Валентина Львовна - действительный член Лесной академии наук Украины, доктор сельскохозяйственных наук, профессор, Украинский научно-исследовательский институт лесного хозяйства и агролесомелиорации им. Г. Н. Высоцкого, ул. Пушкинская, 86, Харьков, 61024, Украина. Тел.: +38(097)371-94-58. E-mail: Valentynameshkova@gmail.com ORCID: https:// orcid.org/0000-0001-6483-2736

Пивовар Татьяна Сергеевна-кандидат сельскохозяйственных наук, старший научный сотрудник, Украинский научноисследовательский институт лесного хозяйства и агролесомелиорации им. Г. Н. Высоцкого, ул. Пушкинская, 86, Харьков, 61024, Украина. Тел.: +38 (097)358-97-49. E-mail: pyvovartatiana@gmail.com ORCID: https:// orcid.org/00000001-7250-8549

Товстуха Александр Владимирович - кандидат сельскохозяйственных наук, заместитель начальника Сумского областного управления лесного и охотничьего хозяйства. Засумская ул. 12a, Сумы, 40030, Украина. Тел. +38(067)540-17-70. E-mail: sekretar@sumylis.gov.ua 
риферийного отмирания кроны и распространения водяных побегов) у семи древесных видов -Acer platanoides L., Alnus glutinosa L., Betula pendula Roth., Fraxinus excelsior L., Quercus robur L., Tilia cordata Mill. и Ulmus laevis Pall.

Исследования проведены в 2018 г. в ГП «Тростянецкое ЛХ» (Левобережная Лесостепь; Сумская область) в 129 рандомизированно выбранных выделах. Для каждого обследованного дерева оценивали диаметр на высоте груди, класс Крафта, категорию санитарного состояния, дефолиацию, периферийное отмирание кроны и распространение водяных побегов. Распространенность дефолиации, периферийного отмирания кроны и водяных побегов определяли как долю деревьев с наличием соответствующих симптомов. Интенсивность проявления каждого параметра оценивали по соответствующим шкалам.

Ни одна порода не была дефолиирована больше чем на $50 \%$. Береза характеризуется наименьшими значениями индекса санитарного состояния $(\mathrm{I}, 6)$ для жизнеспособных деревьев, периферийного отмирания крон $(10 \%)$, распространения водяных побегов $(15,9 \%)$ и доли свежего сухостоя $(0,7 \%)$, однако высокой долей деревьев старого сухостоя $(10,7 \%)$. Дуб характеризуется наибольшими значениями индекса санитарного состояния (II,1), доли деревьев с наличием периферийного отмирания кроны $(45,4 \%)$ и водяных побегов $(21,7 \%)$. Долевое участие деревьев ольхи, липы и клена с нали- чием периферийного отмирания кроны составляло от 21,5 до $25 \%$ и было немного больше для вяза и ясеня (30,9 и 31,3\% соответственно).

Диаметр стволов, класс Крафта, индекс санитарного состояния деревьев значимо коррелирует с параметрами санитарного состояния соответствующих видов, однако большинство связей очень слабые и слабые. Коэффициенты корреляции между диаметром и параметрами санитарного состояния деревьев преимущественно отрицательные, а между остальными параметрами - положительные. Корреляция между индексом санитарного состояния деревьев и уровнем дефолиации - значимая, положительная и высокая для всех проанализированных видов деревьев (от 0,78 для ольхи до 0,9 для березы). Корреляция между индексом санитарного состояния и уровнем периферийного отмирания кроны - положительная и значимая для всех проанализированных видов деревьев, в частности, слабая для ясеня, березы, липы, ольхи и умеренная - для клена, дуба и вяза. Корреляция между индексом санитарного состояния и распространением водяных побегов - значимая и положительная для всех проанализированных видов деревьев, кроме березы, однако очень слабая во всех случаях, кроме вяза, где она слабая.

Ключевые слова: диаметр (диаметр на высоте груди); класс Крафта; индекс санитарного состояния; отпад деревьев; дефолиация; периферийное отмирание кроны; водяные побеги. 